Volume 1 Issue 1, January 2022: pp.49-62 Copyright@ NoLaJ.

Master of Notary, Faculty of Law, Lambung Mangkurat University,

Banjarmasin, South Kalimantan, Indonesia.ISSN: 2808-7860 | e-ISSN: 2808-7348

Open Access at: https://notarylaw.journal.ulm.ac.id/index.php/nolaj

\title{
Asas Keadilan dalam Pengadaan Tanah bagi Pembangunan untuk Kepentingan Umum
}

\author{
Ervan Hari Sudana ${ }^{1}$, Djoni S.Gozali², Akhmadi Yusran ${ }^{3}$
}

${ }^{1}$ Karyawan Notaris dan Pejabat Pembuat Akta Tanah Jl. Mayjen Sutoyo S No.104, Tlk. Dalam, Kec. Banjarmasin Tengah,

Kota Banjarmasin, Kalimantan Selatan 70117,Email: harisudanaervan@ymail.com

${ }^{2}$ Fakultas Hukum Universitas Lambung Mangkurat

Jl.Brigjen H.Hasan Basry, Banjarmasin, Indonesia, 70123

Email:djoni.gozali@ulm.ac.id

${ }^{3}$ Fakultas Hukum Universitas Lambung Mangkurat

Jl.Brigjen H.Hasan Basry, Banjarmasin, Indonesia, 70123

Email: akhmadi.yusran@ulm.ac.id

Submitted : 10-10-2021 Reviewed:28-10-2021 Accepted:04-11-2021

Abstract:The purpose of this research are to analyze the characteristics of the principle of justice in the law of land procurement and the implementation of the principle of justice in land procurement for public interest in the legislation. This research is a normative legal research, and the type of this research is doctrinal research wich systematically corrects and explain the prevailing legal regulations in particular fields through analysis. The regulations wich the researcher is the characteristic of justice in the law on land procurement is from which aspect the characteristic of justice is perceived. The results of this research show that in line with contents of Act Number 2 of 2012 concerning land Procurement For Public Interest, the characteristic of this act indicates that the proper and just compenstation exist because there are public consultants whose function is to reach the understanding and consensus through deliberation with regrad to compensation in the plan of development for public interest. Besides analyzing the characteristic of the law of land procurement, the writer also analyze the implementation of the principle of justice in land procurement for public interestin the legislation in wich the said land compensation must be just at the time of the process of land procurement until after the final process in wich the final process should reflect the principle of justice.

Keywords: Land; Principle of justice; Public Interest

Abstrak:Tujuan dari penelitian ini adalah untuk menganalisis karakterisitk asas keadilan dalam hukum pengadaan tanah dan implementasi asas keadilan dalam pengadaan tanah untuk kepentingan umum dalam peraturan perundang-undangan, jenis penelitian yang diguanakan dalam penelitian ini adalah jenis penelitian hukum normatif, dan tipe penelitian yang digunakan adalah Doctrinal research secara sistematis mengkoreksi dan memperjelas suatu aturan hukum yang berlaku pada 
bidang hukum tertentu dengan cara analisis. Adapaun aturan yang dimaksud oleh penulis yaitu Karakterisitik keadilan dalam hukum pengadaan tanah, yaitu dari sisi mana karakteristik keadilan tersebut dilihat. Menurut hasil penelitian bahwa sesuai dengan isi UU no 2 tahun 2012 tentang pengadaan tanah untuk kepentingan umum, jadi dilihat dari aturan tersebut karakteristik yang terdapat dalam uи no 2 tahun 2012 tersebut yaitu pada penggantian rugi yang layak dan adil yang dimana layak dan adil itu terwujud karena adanya konsultan publik yang dimana fungsinya untuk mencapai kesepahaman dan kesepakatan melalui musyawarah terhadap ganti kerugian dalam perencanaan pembangunan untuk kepentingan umum. Selain menganalisis karakteristik dari hukum pengadaan tanah tersebut penulis juga menganalisis impelentasi asas keadilan dalam pengadaan tanah untuk kepentingan umum dalam peraturan perundang-undangan yang dimana pengadaan tanah itu harus adil pada saat proses pengadaan tanah hingga setelah proses akhir dari pengadaan tanah yang dimana proses akhir tersebut wujud dari pada asas keadilan.

Kata Kunci : Tanah; Asas keadilan; Kepentingan Umum

\section{PENDAHULUAN}

Tanah dalam kehidupan manusia menempati kedudukan yang penting, karena sebagian besar kehidupan manusia bergantung pada tanah. ${ }^{1}$ Tanah merupakan tempat tinggal bagi manusia, di samping itu tanah juga sebagai sumber penghidupan. Bahkan tanah merupakan harta yang dapat dicadangkan untuk kehidupan manusia di masa akan datang, tanah pula yang dijadikan tempat disemayamkannya jenazah orang yang meninggal dunia. ${ }^{2}$ Demikian pentingnya arti tanah bagi kehidupan manusia, maka dalam Undang-Undang Republik Indonesia Nomor 5 Tahun 1960 tentang Peraturan Dasar Pokok-Pokok Agraria yang selanjutnya disebut UUPA hak-hak atas tanah dapat diberikan secara perseorangan maupun secara bersama-sama dengan orang lain. Pemberian hak-hak atas tanah tersebut memberikan kewenangan untuk mempergunakan tanah yang bersangkutan sekedar diperlukan untuk kepentingan yang langsung berhubungan dengan tanah itu. ${ }^{3}$ Tanah adalah salah satu yang wajib dimiliki, dikuasai dan dipertahankan oleh setiap orang. ${ }^{4}$

Hampir separuh penduduk Indonesia menggantungkan roda perekonomian mereka di sector pertanahan, baik dalam skala kecil, menengah bahkan dalam skala berat. ${ }^{5}$ Sementara kondisi tata kelola kota -kota di Indonesia sering kali berubah-ubah sehingga menimbulkan banyaknya masalah pertanahan, hal ini linear dengan bertambahnya jumlah penduduk Indonesia. $^{6}$

Dalam Pasal 2 ayat (1) Undang-Undang Nomor 5 Tahun 1960 tentang UUPA, me-

\footnotetext{
1 Djoni Sumardi Gozali, Hukum Pengadaan Tanah : Asas Kesepakatan Dalam Pengadaan Tanah Bagi Pembangunan Untuk Kepentingan Umum (Yogyakarta: UII Press, 2018).

2 Gozali.

3 Gozali.

4 Yosi Irawan, “Kepemilikan Hak Atas Tanah Yang Merupakan Harta Bersama," Lambung Mangkurat Law Journal 3, no. 1 (2018): 6, https://doi.org/https://doi.org/10.32801/lamlaj.v3i1.64.

5 Dyara Radhite Oryza Fea, Panduan Mengurus Tanah, Rumah Dan Perizinannya (Yogyakarta: Legalitiy, 2018).

${ }^{6}$ Fea.
} 
nyatakan bahwa :

"Atas dasar ketentuan dalam Pasal 33 ayat (3) Undang-Undang Dasar 1945 dan hal-hal sebagaimana yang dimakusd dalam Pasal 1, bumi, air dan ruang angkasa, termasuk kekayaan alam yang terkandung di dalamnya itu pada tingkatan tertinggi dikuasai oleh negara sebagai organisasi kekuasaan seluruh rakyat"

UUPA berpangkal pada pendirian bahwa untuk mencapai apa yang ditetapkan dalam Pasal 33 ayat (3) Undang-Undang Dasar 1945 tidaklah perlu dan tidaklah pada tempatnya bahwa negara sebagai organisasi kekuasaan seluruh rakyat (bangsa) bertindak selaku badan penguasa. Sesuai dengan pangkal pendirian tersebut perkataan "dikuasai" disini bukan berati "dimiliki", akan tetapi pengertian yang memberikan wewenang kepada negara sebagai organisasi kekuasaan seluruh rakyat pada tingkatan tertinggi. ${ }^{7}$

Hak menguasai dari negara tersebut ditujukan untuk mencapai sebesar-besarnya kemakmuran rakyat dalam arti terwujud kebahagiaan dan kesejahteraan bagi seluruh rakyat Indonesia. Namun kepentingan sesuatu masyarakat hukum harus tunduk pada kepentingan nasional dan negara.

Di dalam Pasal 18 Undang-Undang Nomor 5 Tahun 1960 tentang UUPA menyebutkan bahwa :

"Untuk kepentingan umum, termasuk kepentingan bangsa dan negara serta kepentingan bersama dari rakyat, hak-hak atas tanah dapat dicabut, dengan memberikan ganti kerugian yang layak dan menurut cara yang diatur dalam undang-undang.

Apabila kepentingan bangsa dan negara menghendaki diambilnya hak atas tanah, maka pemegang hak atas tanah harus melepaskan atau menyerahkan hak atas tanahnya melalui pencabutan hak atas tanah dengan pemberian ganti kerugian yang layak. Hak atas tanah yang ada pada seseorang atau badan hukum tidak bersifat mutlak, melainkan berfungsi sosial, sehingga pemegang hak atas tanah harus mengedepankan kepentingan bangsa dan negara daripada kepentingan pribadinya. Meskipun kepentingan bangsa dan negara dikedepankan, tidak berarti kepentingan pribadi diabaikan begitu saja, melainkan pemegang hak atas tanah diberikan ganti kerugian yang layak.

Alasan dasar dalam pengadaan tanah, terutama di era reformasi adalah upaya perbaikan perekonomian nasional yang fokus pada percepatan pengembangan dan pembangunan infrasturktur, langkah pemerintah adalah mengambil kebijakan mempercepat proses pengadaan tanah tanah bagi pelaksanaan pembangunan. Tanah banyak dibutuhkan untuk melaksanakan pembangunan yang dilaksanakan oleh pemerintah, pemerintah daerah atau pihak swasta, yang diatur melalui jual-beli, tukar menukar atau dengan cara lain yang disepakti secara sukarela dengan pihak-pihak yang bersangkutan.

Berkaitan dengan Pasal 6 Undang-Undang Nomor 5 Tahun 1960 tentang UUPA, yang menyebutkan bahwa :"

"Semua hak atas tanah mempunyai fungsi sosial"

Fungsi sosial tanah yang dijabarkan di dalam Pasal 6 UUPA, memiliki tujuan yaitu untuk

\footnotetext{
${ }^{7}$ Urip Santoso, Hukum Agraria : Kajian Komprehensif(Jakarta: Kencana, 2012).
} 
menghindari akumulasi dan monopoli kepemilikan tanah untuk segelintir orang. ${ }^{8}$

Asas fungsi sosial hak atas tanah yang ditemukan di dalam Pasal 18 Undang-Undang Nomor 5 Tahun 1960 tentang UUPA, di mana dalam menggunakan hak atas tanah harus mengedepan kepentingan bangsa dan negara serta kepentingan bersama (kepentingan umum) dari seluruh rakyat daripada kepentingan pribadinya. Namun di dalam UUPA tidak ada menyebutkan secara rinci mengenai apa itu kepentingan umum. Hanya ada ditemukan di dalam Pasal 7 UUPA bahwa untuk tidak merugikan kepentingan umum maka pemilikan dan penguasaan tanah yang melampaui batas tidak diperkenankan. Arti kepentingan umum di dalam UUPA tidak dijelaskan, hanya saja terhadap kepentingan umum tersebut jangan sampai menimbulkan "kerugian". Hal ini di dalam Penjelasan Umum II (4) bahwa kepentingan masyarakat dan kepentingan perseorangan harus saling mengimbangi, hingga pada akhirnya tercapai tercapai tujuan pokok kemakmuran, keadilan dan kebahagiaan bagi seluruh rakyat. Keadilan disebutkan di dalam Penjelasan Umum tersebut, di dalam UUPA maupun Penjelasan Umumnya tidak menyebutkan kerugian.

Ketika pemegang hak melepaskan haknya untuk kepentingan bangsa dan negara serta kepentingan umum tersebut, maka pemberian ganti kerugian yang layak yang harus diterima sebagai bentuk perhormatan dan pengakuan terhadap hak individu hak atas tanah yang merelakan melepaskan atau menyerahkan hak atas tanah untuk kepentingan umum. Pengambilan tanah untuk kepentingan umum tanpa disertai ganti kerugian yang layak sama dengan perampasan hak atas tanah. ${ }^{9}$

Layak disini dapat diartikan sebagai "keadilan" yang diterima oleh masyarakat, apakah layak disini bisa berwujud keadilan bagi pemegang hak yang melepaskan haknya. Terhadap ganti kerugian jua harus tetap memperhatikan hak-hak individu yang sudah diambil untuk kepentingan bangsa, negara dan masyarakat umum. Jangan sampai pemegang hak dirugikan atas ganti rugi ini. Keadilan yang seperti apa yang layak untuk mereka yang melepaskan haknya demi kepentingan bangsa, negara dan kepentingan umum.

Sistem yang dianut oleh UUPA lebih condong menganut sistem publikasi negatif di mana hak kepemilikan atas tanah sifatnya tidak mutlak, bisa diadakan perlawanan dari pihak lain yang membuktikan sebaliknya, sistem publikasi negatif yang berlaku diharapakan dapat memberikan keadilan berupa perlindungan hukum bagi pemilik atau yang sesungguhnya berhak atas sebidang tanah untuk mengadakan perlawanan terhadap pihak-pihak lain yang telah mendaftarkan bidang tanah miliknya, untuk menghindari pemilik asli dikemudian hari kehilangan tanah hak miliknya secara sepihak. ${ }^{10}$

Namun yang terjadi adalah ganti kerugian tersebut dirasakan tidak adil oleh masyarakat yang haknya diambil untuk kepentingan umum. Ketidakadilan tersebut dirasa dalam hal bentuk ganti kerugiannya, di mana penolakan atas tawar menawar dengan rakyat pemilik ta-

\footnotetext{
8 Berhard Limbong, Reforma Agraria (Jakarta: Pustaka Margaretha, 2012).

9 Santoso, Hukum Agraria : Kajian Komprehensif.

${ }^{10}$ Putri Fransiska Purnama Pratiwi, "Permasalahan Yuridis Pasal 41 Ayat (3) Undang-Undang Nomor 2 Tahun 2012 Tentang Pengadaan Tanah Bagi Kepentingan Umum,” Lambung Mangkurat Law Jurnal 1, no. 2 (2016): 171-72, https://doi.org/https://doi.org/10.32801/lamlaj.v1i2.17.
} 
nah, memberikan kesan kuat bahwa pengadaan tanah untuk kepentingan umum berlangsung seperti jual-beli, padahal hubungan pemerintah dengan warga pemilik tanah dalam kasus pengadaan tanah mestinya dipahami bukan seperti pembeli dan penjual di pasar, melainkan sebagai para pihak yang berkomitmen bersama-sama membangun Negara. Adapun nilai adil bagi masyarakat bahwa harga yang mereka inginkan berdasarkan kepada nilai pasar tanah, bahan bangunan dan risiko kehilangan hak atas tanah. Jika sesuai ketentuan dasar harga ganti kerugian tersebut masyarakat pasti menyetujuinya.

Banyak kasus pengadaan tanah yang terjadi, salah satunya adalah Pengadaan Tanah di Jalan Veteran Kota Banjarmasin Kalimantan Selatan. Warga melaporkan Pemerintah Kota Banjarmasin mengeksekusi lahan dengan membongkar ratusan bangunan milik warga pada 23 Januari 2015, kemudian melaporkan Pemerintah Kota Banjarmasin dengan tuduhan tindak pidana dan pelanggaran hukum. ${ }^{11}$ Alasan yang juga menjadi permasalahan adalah bahwa jalan Veteran ini melibatkan dua daerah yaitu Kota Banjarmasin dan Kabupaten Banjar karena berbatasan antara Sungai Lulut dan Sungai Tabuk. Pemerintah Kota Banjarmasin tidak bisa bekerja sendiri, apalagi status Jalan Veteran yang merupakan milik Provinsi Kalimantan Selatan. ${ }^{12}$ karena tidak ada persetujuan atau kesepakatan nilai ganti kerugian yang berlarut larut maka uang ganti kerugian diserahkan kepada Pengadilan untuk dibagi kemasyarakat.berdasarkan latar belakang di atas maka penulis membuat rumusan masalah sebagai berikut yang pertama Karakteristik keadilan menurut hukum pengadaan tanah? yang kedua Implemantasi asas keadilan dalam pengadaan tanah untuk kepentingan umum dalam peraturan perundang-undangan?

\section{METODE PENELITIAN}

Dalam penelitian ini,menggunakan jenis penelitian hukum normatif. Penelitian hukum normatif adalah penelitian hukum yang meletakkan hukum sebagai sebuah bangunan sistem norma Penelitian hukum normatif dilakukan untuk menghasilkan argumentasi, teori atau konsep baru sebagai preskripsi dalam menyelesaikan masalah yang sedang dihadapi. Penulis memilih tipe "Doctrinal Research" yaitu secara sistematisasi mengkoreksi dan memperjelas suatu aturan hukum yang berlaku pada bidang hukum tertentu dengan cara melakukan analisis terhadap teks yang bersifat autoritatif yang meliputi bahan hukum primer dan sekunder.

\section{ANALISIS DAN PEMBAHASAN}

\subsection{Karakteristik Keadilan Menurut Hukum Pengadaan Tanah.}

Keadilan berasal dari kata adil, yang artinya tidak berat sebelah, tidak pandang bulu, tidak memihak, berpihak kepada yang benar; berpegang kepada kebenaran, sepatutnya tidak

\footnotetext{
11 "Pembahasan Jalan Veteran Bermasalah," BorneoONews : Suara Rakyat Kalimantan, 2015, https://www. borneonews.co.id/berita/12839-pembebasan-lahan-jalan-veteran-bermasalah.

12 "Masalah Menahun Jalan Veteran Tak Kunjung Selesai :Diajak Berlari, Malah Jalan Kaki," Pro Kalsel :Pro Kalimantan, 2018, https://kalsel.prokal.co/read/news/14478-masalah-menahun-jalan-veteran-tak-kunjung-selesai. html.
} 
sewenang-wenang. ${ }^{13}$ Keadilan adalah sifat (perbuatan, perlakuan, dan sebagainya) yang adil. ${ }^{14}$ Adil tidak memihak, tidak berat sebelah, tidak condong pada salah satu pihak. ${ }^{15} \mathrm{Ke}-$ adilan sifat yang adil, perbuatan yang adil. ${ }^{16}$

Keadilan telah menjadi perhatian sejak zaman dahulu kala. Bangsa Yunani kuno telah memiliki dewi yang khusus menangani keadilan yaitu Themis, ${ }^{17}$ Themis digambarkan sebagai wanita yang memegang timbangan dan suatu untaian barang (cornucopia). Keadilan sering dibedakan dari hukum itu sendiri, terutama apabila orang tidak merasa puas dengan hukum yang ada. ${ }^{18}$ Oleh karenanya ada yang berpendapat bahwa tujuan hukum adalah keadilan. ${ }^{19}$

Keadilan yang tertinggi adalah ketidakadilan yang tertinggi, ungkapan tersebut disatu pihak dengan undang-undang harus dibuat peraturan-peraturan umum yang berlaku bagi setiap orang, sehingga dapat dicapai kepastian hukum. ${ }^{20}$ Di lain pihak, ada keadilan yang menghendaki setiap kasus ditinjau tersendiri, tetapi dengan dibuatnya peraturan umum, berarti keadilan yang menghendaki agar setiap kasus ditinjau tersendiri, harus dikorbankan. Ini dipandang sebagai ketidakadilan yang tertinggi. ${ }^{21}$

Hukum memiliki harapan dan cita-cita yang agung, yakni untuk menuju pada suatu tatanan kehidupan yang lebih baik, tertib, tentram dan damai sebagaimana dikatakan oleh Justanius, bahwa hukum memiliki harapan-harapan, diantaranya "honeste vivere" (hiduplah dengan jujur), "alterum non leadere" (janganlah merugikan orang lain), dan "suum cuique tribure" (berikan kepada orang lain apa yang menjadi haknya). ${ }^{22}$

Harapan-harapan hukum dimaksud esensinya adalah suatu keadilan, artinya hukum menjelmakan keadilan atau hukum harus adil. ${ }^{23}$ Terkait dengan konsep keadilan, hukum Justianus juga mengatakan bahwa "Ius est ars boni et aequi", artinya hukum adalah kesenian tentang yang baik dan yang adil. ${ }^{24}$

Keadilan mempunyai kedudukan yang penting dalam setiap masyarakat, baik masyarakat yang besar maupun masyarakat yang kecil, tanpa memandang pekerjaan dan jenis tingkah lakunya. Namun demikian, dalam kenyataannya kita akan mengalami kesulitan apakah

${ }^{13}$ Tri Kurnia Nurhayati, Kamus Lengkap Bahasa Indonesia : Dengan Ejaan Yang Disempurnakan (Jakarta: Eska Media, 2012).

${ }^{14}$ Nurhayati.

${ }^{15}$ Tim Prima Pena, Kamus Besar Bahasa Indonesia : Edisi Terbaru (Jakarta: Gitamedia Press, n.d.).

${ }^{16}$ Pena.

${ }^{17}$ Donald Albert Rumokoy and Frans Maramis, Pengantar Ilmu Hukum (Jakarta: PT Rajagrafindo Perkasa, 2014).

${ }^{18}$ Rumokoy and Maramis.

${ }^{19}$ Rumokoy and Maramis.

${ }^{20}$ Rumokoy and Maramis.

${ }^{21}$ Rumokoy and Maramis.

${ }^{22}$ Sadjijono, Hukum Antara Sollen Dan Sein (Dalam Persfektif Praktek Hukum Di Indonesia) (Surabaya: Laksbang, 2017).

${ }^{23}$ Sadjijono.

${ }^{24}$ Mohammad Koesno, Dasar Dan Metode Ilmu Hukum Positif (Surabaya: Pusat Penerbitan dan Percetakan Unair (AUP, 2010). 
sesuatu itu adil atau tidak karena banyaknya bentuk keadilan. Bagaimanapun juga semua bentuk itu dapat dikembalikan pada rumusan pendek, yaitu : "Berikan kepada setiap orang apa yang menjadi haknya, itulah keadilan". ${ }^{25}$ Berkaitan dengan hal tersebut maka di dalam menegakkan keadilan manusia dituntut untuk bijaksana karena dengan kebijaksanaanlah orang dapat memberikan seseorang apa yang seharusnya, apa yang menjadi haknya. ${ }^{26}$

Jhon Rawls dalam bukunya $A$ theory of Justice berpendapat bahwa keadilan adalah kebajikan utama dalam isntitusi social, sebagaimana kebenaran dalam system pemikiran ${ }^{27}$ Sebagian kebajikan utrama umat manusia, kebenaran dan keadilan tidak bisa diganggu gugat. ${ }^{28}$ Lebih lanjut, Rawls mengatakan bahwa perlu adanya keseimbangan, kesebandingan, dan keselarasan (harmony) antara kepentingan pribadi dengan kepentingan masyarakat, termasuk di dalam Negara. ${ }^{29}$ Keadilan merupakan nilai yang tidak dapat ditawar-tawar karena hanya dengan ekadilanlah ada jaminan kestabilan dan ketentraman dalam hidup manusia. ${ }^{30}$ Untuk itu jauh sebelumnya Aristotelis merumuskan keadilan kedalam dua jenis yaitu: ${ }^{31}$

1. Keadilan umum

Kebajikan (kebaikan) secara menyeluruh dan sempurna, yang wajib dilaksanakan demi kepentingan umum, kepentingan Negara. Keadilan umum ini menurut Aristotelis sama dengan ekadilan legal dalam arti menurut perbuatan agar sesuai dengan ketentuan undang-undang/hukum Negara yang ditujukan kepada kesejahteraan umum, adil dan makmur.

2. Keadilan khusus

Keadilan khusus merupakan kebajikan khusus seperti keberanian, kebijaksanaan, dugaan antara (matigheid)

Selain teori etis yang memberikan pendapat bahwa tujuan hukum adalah keadilan, teori campuran juga memberikan pendapat bahwa tujuan pokok dan pertama dari hukum adalah ketertiban, di samping ketertiban tujuan lain dari hukum adalah tercapainya keadilan yang berbeda-beda isi dan ukurannya menurut masyarakat dan zamannya. ${ }^{32}$

Adapun di dalam hidup bermasyarakat manusia terdapat 2 (dua) aspek, yaitu aspek fisik dan aspek ekistensi. ${ }^{33}$ Oleh karena itu, hukum harus ditujukan untuk memenuhi baik kebutuhan aspek fisik maupun aspek eksistensial manusia dalam hidup bermasyarakat. ${ }^{34}$ Gustav Radbruch, diantaranya menyatakan bahwa cita hukum tidak lain daripada keadilan, ${ }^{35}$ yang

\footnotetext{
${ }^{25}$ Zaeni Asyhadie and Arief Rahman, Pengantar Ilmu Hukum (Jakarta: PT Rajagrafindo Perkasa, 2014).

${ }^{26}$ Asyhadie and Rahman.

${ }^{27}$ Jhon Rawls, A Theory of Justice (Yogyakarta: Pustaka Pelajar, 2006).

${ }^{28}$ Rawls.

${ }^{29}$ Rawls.

${ }^{30}$ Bernard Limbong, Hukum Agraria Nasional (Jakarta: Margaretha Pustaka, 2012).

${ }^{31}$ Asyhadie and Rahman, Pengantar Ilmu Hukum.

${ }^{32}$ Asyhadie and Rahman.

${ }^{33}$ Peter Mahmud Marzuki, Pengantar Ilmu Hukum (Jakarta: Kencana, 2015).

${ }^{34}$ Marzuki.

${ }^{35}$ Marzuki.
} 
kemudian ia menyatakan bahwa "Est autem jus a justitia, sicut a matre sua ergo prius fuit justitia quam jus, yang apabila diterjemahkan secara bebas keadilan adalah suatu keinginan yang terus menerus dan tetap untuk memberikan kepada orang apa yang menjadi haknya. ${ }^{36}$ Esensi keadilan berpangkal pada moral manusia. Mengapa demikian, ${ }^{37}$ karena esensi aturan hukum adalah pencerminan moral, hal ini menurut pandangan Dworkin karena di dalam hukum memang terkandung nilai-nilai moral. ${ }^{38}$

Jadi dari uraian sub bahasan bagian A yaitu Filosofis Keadilan dan Teori Keadilan dapat peneliti simpulkan bahwa keadilan itu merupakan bagian dari tujuan atau cita hukum. Cita hukum merupakan keadilan. Keadilan itu memberikan kepada orang apa yang menjadi haknya .wujud keadilan merupakan kebahagiaan .sedangkan teori keadilan salah satunya adalah teori etis, di mana teori ini memberikan bahwa keadilan itu mempunyai kedudukan yang penting dalam kehidupan. Makna keadilan sangat sulit ditafsirkan, namun yang terpenting bahwa keadilan tersebut diberikan sesuai apa yang menjadi haknya.

Secara normatif di dalam Pasal 6 UUPA ditegaskan bahwa semua hak atas tanah mempunyai fungsi sosial. Hal ini telah dinyatakan bahwa di dalam Pasal 33 ayat (3) UUD 1945, di mana frasa "fungsi sosial" tidak disebutkan secara eksplisit dalam UUD 1945, khususnya Pasal 33 ayat (3), namun secara implisit, ayat ini harus ditafsirkan bahwa fungsi sosial dari hak milik primer dapat diartikan sebagai hak milik yang tidak boleh dibiarkan merugikan kepentingan umum masyarakat umum. ${ }^{39}$

Dalam Penjelasan Pasal 6 UUPA dinyatakan bahwa seseorang tidak boleh semata-mata mempergunakan untuk pribadinya pemakaian atau tidak dipakainya tanah yang menyebabkan kerugian dalam masyarkat. Dalam ketentuan UUPA dijelaskan bahwa memiliki hak berati harus atau wajib mempergunakannya dan dalam mempergunakannya harus diingat juga untuk kepentingan umum sesuai dengan tujuan pemberian hak tersebut. Begitu juga dengan hak individu, bahwa hak itu sudah tercakup dalam pengertian fungsi social (dwi tunggal). Pencantuman fungsi social di dalam peraturan perundang-undangan merupakan penegasan dari hukum adat itu sendiri.

Konsekuensi dari fungsi sosial adalah: ${ }^{40}$

1. Bahwa tidak dapat dibenarkan untuk menggunakan atau menggunakan tanah hanya untuk kepentingan pribadi pemegang haknya, apalagi menimbulkan kerugian masyarakat.

2. Penggunaan tanah harus disesuaikan dengan keadaan dan sifat dari haknya sehingga bermanfaat, baik bagi kesejahteraan dan kebahagiaan pemegang hak maupun bagi masyarakat dan Negara.

3. Penggunaan dan pemanfaatan tanah harus memperhatikan rencana tata ruang maupun instrument penatagunaan tanah lainnya yang ditetapkan secara sah oleh pihak yang berwenang.

\footnotetext{
${ }^{36}$ Marzuki.

${ }^{37}$ Marzuki.

${ }^{38}$ Marzuki.

${ }^{39}$ Limbong, Hukum Agraria Nasional.

${ }^{40}$ Limbong.
} 
4. Pemegang hak atas tanah wajib memelihara tanah dengan baik dalam arti menambah kesuburan dan mencegah kerusakan tanah tersebut.

5. Adanya kerelaan hak atas tanah dicabut demi kepentingan umum.

Pengadaan tanah untuk kepentingan umum merupakan salah satu manifestasi dari fungsi sosial hak atas tanah. Pengadaan tanah dipandang sebagai langkah awal dari pelaksanaan pembangunan yang merata untuk meningkatkan kesejahteraan rakyat atau masyarakat itu sendiri, baik yang akan digunakan untuk kepentingan umum maupun kepentingan swasta. Pengadaan tanah untuk pembangunan tidak hanya dapat dilakukan atas dasar persetujuan dari pemegang hak atas tanah mengenai dasar dan bentuk ganti rugi yang diberikan kepada pemegang hak atas tanah itu sendiri.

yang seharusnya menjadi haknya. Di sini di dalam pengadaan tanah untuk kepentingan umum, di mana subyek hukum melepaskan haknya untuk kepentingan umum. Ketika pemegang hak melepaskan haknya, keadilan yang harus diterima oleh subyek hak tersebut adalah dalam hal ganti kerugian yang layak, yang bisa dinikmati subyek seperti semula. Ganti kerugian yang didapat tidak saja dalam bentuk fisik namun juga non fisik. Sepatutnya pemberian ganti kerugian tersebut tidak membawa dampak kerugian kepada pemegang hak atas tanah yang kehilangan haknya tersebut melainkan membawa dampak pada tingkat kehidupan yang lebih baik atau minimal sama pada waktu sebelum terjadinya kegiatan pembangunan.

\subsection{Implementasi Asas Keadilan dalam Pengadaan Tanah untuk Kepentingan umum dalam Peraturan Perundang-Undangan}

Keadilan adalah kebijakan utama dalam institusi sosial, sebagaimana kebenaran dalam sistem pemikiran ${ }^{41}$, bahkan juga tindakan-tindakan tertentu, termasuk keputusan, penilaian dan tuduhan.Banyak hal dikatakan adil dan tidak adil: tidak hanya hukum, institusi, dan sistem sosial bahkan juga tindakan-tindakan tertentu, termasuk keputusan, penilaian dan tuduhan. ${ }^{42}$ Subyek utama keadilan adalah struktur dasar masyarakat, atau lebih tepatnya, cara lembaga-lembaga sosial utama mendistribusiakan hak dan kewajiban fundamental serta menentukan pembagian keuntungan dari kerja sama sosial. ${ }^{43}$.

Jadi keadilan yang layak disebut adil dalam ganti kerugian dalam pengadaan tanah untuk kepentingan umum itu seperti apa, bahwa penggadaan tanah penggantian kerugian oleh Negara harus ada pola atau formula yang merefleksikan keadilan sebagai personafikasi penghormatan hak asasi pemilik tanah. ${ }^{44}$ Sebenarnya kewajiban Negara membayar ganti rugi tidak harus karena ada kelalaian dalam pelaksanaan tugas umumnya, tetapi condition sine qua non Negara tetap membayar ganti rugi meskipun Negara tidak melakukan kelalaian

\footnotetext{
${ }^{41}$ Rawls, A Theory of Justice.

${ }^{42}$ Rawls.

${ }^{43}$ Rawls.

${ }^{44}$ Gunanegara, Rakyat Dan Negara : Dalam Pengadaan Tanah Untuk Pembangunan (Pelajaran Filsafat, Teori Ilmu, Dan Yuridprudensi) (Jakarta: PT.Tatanusa, 2008).
} 
atau kesalahan dalam menjalankan tugas umumnya. ${ }^{45}$ Dengan kata lain, meskipun Negara tidak melakukan melanggar hukum tetapi wajib memberikan ganti kerugian, yaitu terutama yang berkaitan dengan masalah pengadaan tanah atau pencabutan hak milik untuk kepentingan umum, sebagaimana teori yang berkembang di Perancis "responssability sans faute", atau yang berkembang di Belanda "rechmatige overheidsdaden". ${ }^{46}$

Berbeda dengan normatifnya, musyawara penetapan ganti kerugian memang seolah mewujudkan namun dalam proses untuk mencapai kata sepakat banyak hal-hal yang mencederai asas kesepakatan. Hal ini seperti pendapat Ediwarman yang menyebutkan bahwa dalam penetapan ganti rugi tanah sering yang menjadi korban adalah pemilik tanah dan yang berkepentingan dengan tanah baik individu atau masyarakat, badan hukum (pengusaha) serta penyalahgunaan wewenang/kekuasaan oleh orang-orang yang mencari pemenuhan kepentingan dengan melanggar hak asasi orang lain. ${ }^{47}$

Proses musyawarah yang semula bertujuan untuk mewujudkan kesepakatan untuk menetapkan ganti kerugian, bergeser menjadi proses indoktrinasi atau penyuluhan pembangunan yang jauh dari proses perundingan ganti kerugian. ${ }^{48}$

Pemerintah harus memperhatikan aspek-aspek di dalam melakukan pembayaran ganti kerugian, yaitu melalui aspek:49

1. Kesebandingan

Ukuran untuk kesebandingan antara hak yang hilang dengan pengantiannya harus adil menurut hukum dan menurut kebiasaan masyarakat yang berlaku umum.

2. Layak

Selain sebanding ganti rugi harus layak jika penggantian dengan hal ini yang tidak memiliki kesaman dengan hak yang telah hilang

3. Perhitungan Cermat

Perhitungan harus cermat, termasuk di dalamnya penggunaan waktu, nilai dan derajat.

Demi keadilan di dalam pengadaan tanah untuk kepentingan umum, di dalam peraturan perundang-undangan yang terkait dengan ganti kerugian tersirat beberapa asas hukum demi terciptanya keadilan dan perlindungan hukum bagi korban pembebasan tanah. Oleh karena itu pemerintah seyogyanyalah memperhatikan asas-asas hukum ketika memberikan ganti kerugian pada warganya yang menjadi korban pembebasan lahan. Asas-asas tersebut antara lain: ${ }^{50}$

Dalam mengimplementasikan asas keadilan dalam pengadaan tanah untuk kepentin-

\footnotetext{
${ }^{45}$ Gunanegara.

${ }^{46}$ Paulus E. Lotulung, Beberapa Sistem Tentang Kontrol Segi Hukum Terhadap Pemerintah (Jakarta: Bhanua Ilmu Populer, n.d.).

${ }^{47}$ Ediwaman, Perlindungan Hukum Bagi Korban Kasus-Kasus Pertanahan (Medan: Pustaka Bangsa Press, 2009).

${ }^{48}$ Gunanegara, Rakyat Dan Negara : Dalam Pengadaan Tanah Untuk Pembangunan (Pelajaran Filsafat, Teori Ilmu, Dan Yuridprudensi).

${ }^{49}$ Tatik Janur Habibi, "Pelaksanaan Penetapan Ganti Rugi Dan Bentuk Pengawasan Panitia Pengadaan Tanah Pada Proyek Pembangunan Terminal Abimanyu" (Universitas Dipenegoro, 2007).

${ }^{50}$ Ediwarman, "Perlindungan Hukum Bagi Korban Kasus-Kasus Pertanahan Di Sumatera Utara" (Program Pascasarjana Universiats Sumatera Utara, 2001).
} 
gan umum dalam peraturan perundang-undangan, dalam kegiatan pengadaan tanah untuk kepentingan umum dengan tegas dilaksanakan atas dasar asas keadilan, yaitu memberikan jaminan penggantian yang layak kepada pihak yang berhak dalam proses pengadaan tanah sehingga mendapatkan kesempatan untuk dapat melangsungkan kehidupan yang lebih baik.

Menurut John Rawls dalam bukunya A Theory of Justice, keadilan adalah kebajikan utama dalam institusi sosial, sebagaimana kebenaran dalam sistem pemikiran. Lebih lanjut ia mengatakan bahwa sebagai kebajikan utama umat manusia, kebenaran dan keadilan tidak bisa diganngu gugat. ${ }^{51}$ Pada bagian lain tulisannya, Rawls mengemukan bahwa keadilan adalah keseimbangan, kesebandingan, dan keselarasan antara kepentingan masyarakat umum, termasuk Negara. ${ }^{52}$ Teori keadilan John Rawls ini dibangun dari kritiknya atas teori keadilan utilitarianisme yang dipelopori oleh Jeremy Bentham dan kemudian dikembangkan oleh John Stuart Mill. Menurut Bentham dan kemudian dikembangkan oleh John Stuart Mill. Menurut Bentham, tujuan masyarakat adalah mencapai kebahagian yang paling besar bagi sejumlah orang yang sebesar mungkin (the greatest happiness of the greatest number). ${ }^{53}$

Bertitik dari kegagalan teori-teori sebelumnya, dengan menghindari kelemahan utilitarianisme sembari mempertahankan kekuatan yang sama, John Rawls menawarkan suatu bentuk penyesuaian yang terkait dengan problematika kehilangan dengan membangun teori keadilan berbasis kontrak. Menurutnya teori keadilan yang memadai harus dibentuk dengan pendekatan kontrak, di mana asas-asas keadilan yang dipilih bersama benar-benar merupakan hasil kesepakatan bersama dari semua person yang bebas, rasional, dan sederajat. Hanya melalui pendekatan kontrak sebuah teori keadilan mampu menjamin pelaksanaan hak dan sekaligus mendistribusikan hak kewajiban secara adil bagi semua orang. Lebih jauh Rawls mengatakan bahwa suatu konsep keadilan yang baik haruslah bersifat kontraktual. Setiap konsep keadilan yang tidak berbasis kontraktual harus dikesampingkan demi kepentingan keadilan itu sendiri. ${ }^{54}$ Teori Rawls ini mengakomodasi pribadi individu secara serius tanpa mempertaruhkan kesejahteraan atau hak-haknya demi kebaikan orang lain, sekaligus menawarkan sebuah metode yang konkret untuk membuat keputusan paling fundamental mengenai keadilan distributif, yaitu keadilan sebagai kesetaraan (justice asfairness). ${ }^{55}$

Keadilan sebagai kesetaraan (justice asfairness) ini ditandai dengan adanya prinsip rasionalitas, kebebasan, dan kesamaan. Disini diperlukan prinsip-prisip yang lebih mengutamakan asas hak daripada asas manfaat. Dalam hubungan ini lah John Rawls mengemukakakn bahwa dua prinsip keadilan, sebagai berikut: ${ }^{56}$

1. The first principles holds that each person is entitled to the most extensive system of

\footnotetext{
${ }^{51}$ Rawls, A Theory of Justice.

${ }^{52}$ Limbong, Hukum Agraria Nasional.

${ }^{53}$ Theo Huijber OSC, Filsafat Hukum Dalam Lintasan Sejarah (Yogyakarta: Yayasan Kanisius, 1990).

${ }^{54}$ Agus Yudha Hernoko, Hukum Perjanjian Asas Proporsionalitas Dalam Kontrak Komersial (Jakarta: Prenada Media Group, 2009).

${ }^{55}$ Karen Leback, Teori-Teori Keadilan (Six Theories of Justice) (Bandung: Nusa Media, 2012).

${ }^{56}$ N.E. Simmonds, Central Issues in Jurisprudece Justice, Law and Rights, Cetakan II (London: Thomas Sweet \& Maxwell, 2002).
} 
basic liberties that is compatible with a similar system for everyone else.

2. The secon prinsciples holds that social and economic inequalities are just only in so far as they work to the advantage of the people is society.

Beranjak dari pendapat inilah, maka hukum sebagai salah satu unsur susunan dasar masyarakat, harus mengatur sedemikian rupa berdasarkan dua prinsip, yaitu pertama, prinsip kesamaan hak (the greatest equal principles), menetapkan kebebasan yang sama bagi setiap orang untuk mendapat akses pada kekayaan, pendapat, makanan, perlindungan, kewibawaan, kekuasaan, harga diri, hak-hak dan kebebasan. Kedua, prinsip perbedaan (the different principles) dan prinsip persamaan atas kesempatan (the principles of fair equality of opportunity), dimaksudkan memberikan kesempatan yang sama bagi semua orang (termasuk mereka yang paling kurang beruntung) untuk mencapai prospek kesejahteraan, pendapatan dan otoritas. ${ }^{57}$ John Rawls memberikan pedoman untuk pendapatan untuk menerapkan masing-masing prinsip tersebut. Prinsip kesamaan hak (the greatest equal principles), harus lebih diprioritaskan dari prinsip perbedaan dan prinsip persamaan atas kesempatan (the different principles and the principles of fair equality opportunity). Sedangkan (the principle of fair equality of opportunity) harus lebih diprioritaskan dari (the different principles). ${ }^{58}$

Jika diperhatikan ketentuan tentang ganti kerugian dalam peraturan perundang-undangan mengenai Pengadaan Tanah untuk Kepentingan Umum selama ini cenderung merugikan pihak pemegang hak atas tanah. Pertama, kerugian yang diganti hanyalah kerugian fisik seperti tanah, bangunan dan tanaman saja, sedangkan kerugian non fisik tidak diperhitungkan. Kedua, dasar perhitungan besarnya ganti kerugian atas tanah bukan atas dasar harga sebenarnya atau harga pasar.

Pada dasarnya ganti rugi merupakan pemberian ganti atas kerugian yang diderita oleh pemegang hak atas tanah atas beralihnya hak tersebut..$^{59}$ Dalam presfektif hukum keperdataan menurut Bernard Limbong, ganti perbuatan yang menyebabkan kerugian diderita oleh salah satu pihak yang melakukan kesepakatan/konsensus. ${ }^{60}$ Atas dasar pengertian ini, maka bentuk ganti rugi yang ditawarkan semestinya tidak hanya ganti kerugian fisik yang hilang, tetapi juga kerugian non fisik. Di samping kerugian fisik, seperti hilangnya tanah, rumah dan tanaman, pemegang hak atas tanah juga harus mendapat ganti atas kerugian nonfisik (sosiologis dan filosofis). Kerugian sosiologis terkait ketercabutan kehidupan sosial pemegang hak atas tanah di tempat lain, seperti lingkungan tempat tinggal, pertemanan, sekolah, keagamaan, perkumpulan atau peguyuban. ${ }^{61}$ Kerugian filosofis seperti nilai sejarah tanah, kenyamanan, ketenangan, kenangan dan kenikmatan-kenikmatan di tempat lama. ${ }^{62}$

\footnotetext{
${ }^{57}$ Austin M. Chinhengo, Essensial Juriprudensi (Essensial Law Series) (London: Cavendish Publishing, 1995).

${ }^{58}$ Chinhengo.

${ }^{59}$ Gozali, Hukum Pengadaan Tanah : Asas Kesepakatan Dalam Pengadaan Tanah Bagi Pembangunan Untuk Kepentingan Umum.

${ }^{60}$ Limbong, Hukum Agraria Nasional.

${ }^{61}$ Limbong.

${ }^{62}$ Limbong.
} 


\section{PENUTUP}

Jadi dapat disimpulkan bahwa Implementasi Asas Keadilan dalam Pengadaan Tanah untuk Kepentingan Umum dalam Peraturan Perundang-Undangan, bahwa di dalam pengadaan tanah untuk kepentingan umum, asas keadilan harus memberikan jaminan penggantian yang layak. Layak artinya adil, jadi pengadaan tanah untuk kepentingan umum itu harus adil pada saat proses pengadaan tanah hingga setelah proses akhir dari pengadaan tanah yaitu hasil ahkir yang merupakan wujud asas keadilan dengan pemberian ganti kerugian dan kehidupan lebih baik setelah ganti kerugian.

Karakteristik Keadilan dalam Pengadaan Tanah Bagi Pembangunan Untuk Kepentingan Umum dalam Hukum Pengadaan tanah adalah adanya konsultan publik yang merupakan proses komunikasi dialogis atau musyawarah antara pihak yang berkepentingan guna mencapai kesepahaman dan kesepakatan dalam perencanaan pembangunan bagi pembangunan untuk kepentingan umum adanya musyawarah terhadap ganti kerugian, dan ketika ada penolakan lagi dari masyarakat, terakhir penyelesaiannya dilakukan melalui lembaga peradilan disertai dengan penitipan ganti kerugian di pengadilan, musyawarah lah solusi yang menjadi karakteristik nya dalam pengadaan tanah untuk kepentingan umum.

\section{REFERENSI}

Asyhadie, Zaeni, and Arief Rahman. Pengantar Ilmu Hukum. Jakarta: PT Rajagrafindo Perkasa, 2014.

Chinhengo, Austin M. Essensial Juriprudensi (Essensial Law Series). London: Cavendish Publishing, 1995.

Ediwaman. Perlindungan Hukum Bagi Korban Kasus-Kasus Pertanahan. Medan: Pustaka Bangsa Press, 2009.

Ediwarman. "Perlindungan Hukum Bagi Korban Kasus-Kasus Pertanahan Di Sumatera Utara." Program Pascasarjana Universiats Sumatera Utara, 2001.

Fea, Dyara Radhite Oryza. Panduan Mengurus Tanah, Rumah Dan Perizinannya. Yogyakarta: Legalitiy, 2018.

Gozali, Djoni Sumardi. Hukum Pengadaan Tanah : Asas Kesepakatan Dalam Pengadaan Tanah Bagi Pembangunan Untuk Kepentingan Umum. Yogyakarta: UII Press, 2018.

Gunanegara. Rakyat Dan Negara : Dalam Pengadaan Tanah Untuk Pembangunan (Pelajaran Filsafat, Teori Ilmu, Dan Yuridprudensi). Jakarta: PT.Tatanusa, 2008.

Habibi, Tatik Janur. "Pelaksanaan Penetapan Ganti Rugi Dan Bentuk Pengawasan Panitia Pengadaan Tanah Pada Proyek Pembangunan Terminal Abimanyu." Universitas Dipenegoro, 2007.

Hernoko, Agus Yudha. Hukum Perjanjian Asas Proporsionalitas Dalam Kontrak Komersial. Jakarta: Prenada Media Group, 2009.

Irawan, Yosi. "Kepemilikan Hak Atas Tanah Yang Merupakan Harta Bersama." Lambung Mangkurat Law Journal 3, no. 1 (2018): 6. https://doi.org/https://doi.org/10.32801/lamlaj. v3i1.64.

Koesno, Mohammad. Dasar Dan Metode Ilmu Hukum Positif. Surabaya: Pusat Penerbitan dan 
Percetakan Unair (AUP, 2010.

Leback, Karen. Teori-Teori Keadilan (Six Theories of Justice). Bandung: Nusa Media, 2012.

Limbong, Berhard. Reforma Agraria. Jakarta: Pustaka Margaretha, 2012.

Limbong, Bernard. Hukum Agraria Nasional. Jakarta: Margaretha Pustaka, 2012.

Lotulung, Paulus E. Beberapa Sistem Tentang Kontrol Segi Hukum Terhadap Pemerintah. Jakarta: Bhanua Ilmu Populer, n.d.

Marzuki, Peter Mahmud. Pengantar Ilmu Hukum. Jakarta: Kencana, 2015.

Pro Kalsel :Pro Kalimantan. "Masalah Menahun Jalan Veteran Tak Kunjung Selesai :Diajak Berlari, Malah Jalan Kaki,” 2018. https://kalsel.prokal.co/read/news/14478-masalahmenahun-jalan-veteran-tak-kunjung-selesai.html.

Nurhayati, Tri Kurnia. Kamus Lengkap Bahasa Indonesia : Dengan Ejaan Yang Disempurnakan. Jakarta: Eska Media, 2012.

OSC, Theo Huijber. Filsafat Hukum Dalam Lintasan Sejarah. Yogyakarta: Yayasan Kanisius, 1990.

BorneoONews : Suara Rakyat Kalimantan. "Pembahasan Jalan Veteran Bermasalah," 2015. https://www.borneonews.co.id/berita/12839-pembebasan-lahan-jalan-veteran-bermasalah.

Pena, Tim Prima. Kamus Besar Bahasa Indonesia : Edisi Terbaru. Jakarta: Gitamedia Press, n.d.

Pratiwi, Putri Fransiska Purnama. "Permasalahan Yuridis Pasal 41 Ayat (3) Undang-Undang Nomor 2 Tahun 2012 Tentang Pengadaan Tanah Bagi Kepentingan Umum." Lambung Mangkurat Law Jurnal 1, no. 2 (2016): 171-72. https://doi.org/https://doi.org/10.32801/ lamlaj.v1i2.17.

Rawls, Jhon. A Theory of Justice. Yogyakarta: Pustaka Pelajar, 2006.

Rumokoy, Donald Albert, and Frans Maramis. Pengantar Ilmu Hukum. Jakarta: PT Rajagrafindo Perkasa, 2014.

Sadjijono. Hukum Antara Sollen Dan Sein (Dalam Persfektif Praktek Hukum Di Indonesia). Surabaya: Laksbang, 2017.

Santoso, Urip. Hukum Agraria : Kajian Komprehensif. Jakarta: Kencana, 2012.

Simmonds, N.E. Central Issues in Jurisprudece Justice, Law and Rights. Cetakan II. London: Thomas Sweet \& Maxwell, 2002.

\section{Peraturan Perundang-Undangan}

Undang-Undang Republik Indonesia Nomor 5 Tahun 1960 tentang Peraturan Dasar PokokPokok Agraria (Lembaran Negara Republik Indonesia Tahun 1960 Nomor 104, Tambahan Lembaran Negara Republik Indonesia Nomor 2043)

Undang-Undang Republik Indonesia Nomor 2 Tahun 2012 tentang Pengadaan Tanah bagi Pembangunan untuk Kepentingan Umum (Lembaran Negara Republik Indonesia Tahun 2012 Nomor 22, Tambahan Lembaran Negara Republik Indonesia Nomor 5280) 